\title{
MOLECULAR TYPING OF BACTERIAL STRAINS ISOLATED FROM THE CLINICS OF SURGERY AND FACE TRAUMATOLOGY AT RIBEIRÃO PRETO UNIVERSITY
}

Thesis: M. V. Pimenta Rodrigues submitted this thesis for his Master's in Biotechnology at the Biotechnology Department, Ribeirão Preto University, UNAERP, Ribeirão Preto, São Paulo State, Brazil, 2006.

Advisors: Professor Rosemeire Cristina Linhari Rodrigues Pietro and Professor Bianca W. Bertoni.

\begin{abstract}
The number of infectious illnesses and cross infection is spreading drastically among the professionals of the dentistry area. Controlling infections in dental offices is one of the greatest challenges for dentists and researchers of this area. In practice, contacts between professionals and infected patients are relatively common. The transmission of infectious illnesses from the health professionals to their patients is also possible, either by direct contact or due to lack of cares in relation to biosafety, increasing the cycle of cross infection. Molecular typing is necessary since these methods are an important tool to investigate the epidemiology of bacterial infections. Moreover, they are important for supplying information and precedents through the analysis of the infectious agents eletrophoretic profile. The aim of the present work was to analyze by molecular typing the genomic profile of aerobic bacteria isolated from the Clinics of Surgery and Face Traumatology, Ribeirão Preto University, through the technique of Random Amplified Polymorphic DNA (RAPD) and grouped based on similarity coefficients. Of two carried out collections, 55 strains were isolates belonging to the following groups: 12 Staphylococcus aureus; 13 Klebsiella oxytoca; 7 Klebsiella pneumoniae; 8 Pseudomonas aeruginosa; 5 Hafnia alvei; 5 Proteus vulgaris; 4 Escherichia coli; and 1 Proteus mirabilis. The adopted molecular typing strategy allowed the determination of the persistence of definitive strains at the collection environment, besides the identification of strains proceeding from the hands and gloves of the surgeon dentists, which could have been found in distant places as sinks and reflectors.
\end{abstract}

KEY WORDS: RAPD technique, bacterial molecular typing, dental office.

\section{CORRESPONDENCE TO:}

MARCUS VINICIUS PIMENTA RODRIGUES, Departamento de Doenças Tropicais e Diagnóstico por Imagem da Faculdade de Medicina de Botucatu, UNESP, Distrito de Rubião Jr, S/N, 18618-000, Botucatu-SP, Brasil. Phone: 55143811 6212. Email: marcus.rodrigues@fmb.unesp.br. 